\title{
Sugarcane-Bagasse Trichokompos Optimalization using Trichoderma sp. (LBKURCC1 dan LBKURCC2) and Pseudomonas szutzeri (LBKURCC54 dan LBKURCC59)
}

\section{Optimalisasi Trichokompos dari Ampas Tebu dengan Jamur Trichoderma sp. (LBKURCC1 dan LBKURCC2) serta Bakteri Selulolitik Pseudomonas szutzeri (LBKURCC54 dan LBKURCC59)}

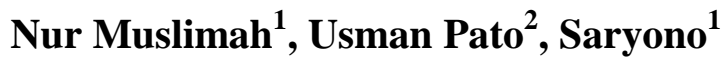 \\ ${ }^{1}$ Program Studi Kimia Fakultas Matematika dan Ilmu Pengetahuan Alam, \\ Universitas Riau, Pekanbaru, 28293 \\ ${ }^{2}$ Program Studi Teknologi Hasil Pertanian Fakultas Pertanian, Universitas Riau, 28293 \\ *saryono@lecturer.unri.ac.id
}

\begin{abstract}
Sugarcane (Saccharum officinarum) is a plant that is widely used as raw material for making sugar and can be enjoyed directly by extracting the juice. While the pulp has not been utilized and is often disposed of as waste. This study aims to make compost using Trichoderma (LBKURCC1 and LBKURCC2) and Pseudomonas (LBKURCC54 and LBKURCC59) as bioactivators. The composting process is done by mixing bagasse and chicken manure with a ratio of $2: 1$ and adding isolate fungus Trichoderma sp. and Pseudomonas stutzeri bacteria as activator with several combinations on compost media with 5 treatment. Compost treatment includes P0 (control), P1 (J1_J2_B1), P2 (J1_J2_B2), P3 (J1_B1_B2), P4 (J2_B1_B2) and P5 (J1_J2_B1), P3 (J1_J2_B1_B2). The process of composting bagasse is done in a poly bag. Analyzed of compost quality was determined based on parameters of temperature, water content and the levels of $\mathrm{C} / \mathrm{N}$ ratio observed for 18 days. In this study, the use of Trichoderma (LBKURCC1 and LBKURCC2) and Pseudomonas (LBKURCC54 and LBKURCC59) as bioactivators in a mixture of compost material gave a significant difference to control at the $\mathrm{C} / \mathrm{N}$ ratio with a value of $\mathrm{P}>0.05$. The highest C/N ratio is from P5 (28.43) and the lowest is from P2 (5.17).
\end{abstract}

Keywords: Bagasse, bioactivator, Pseudomonas, trichocompost, Trichoderma

\begin{abstract}
ABSTRAK
Tebu (Saccharum officinarum) merupakan tanaman yang banyak digunakan sebagai bahan baku pembuatan gula pasir dan dapat dinikmati secara langsung dengan diambil sarinya. Sementara itu ampasnya belum termanfaatkan dengan baik dan sering dibuang sebagai limbah. Ampas tebu dapat dimanfaatkan sebagai bahan baku pembuatan kompos karena mengandung kadar selulosa yang tinggi. Penelitian ini bertujuan untuk membuat kompos menggunakan Trichoderma (LBKURCC1 dan LBKURCC2) dan Pseudomonas (LBKURCC54 dan LBKURCC59) sebagai bioaktivator. Proses pengomposan dilakukan dengan mencampurkan ampas tebu dan kotoran ayam dengan perbandingan 2:1 serta penambahan isolat jamur Trichoderma sp (J1_J2) dan bakteri Pseudomonasstutzer (B1_B2) sebagai aktivator dengan beberapa kombinasi pada media kompos dengan 5 perlakuan. Perlakuan meliputi P0 (kontrol), P1 (J1_J2_B1), P2 (J1_J2_B2), P3 (J1_B1_B2), P4 (J2_B1_B2) dan P5 (J1_J2_B1_B2). Proses pengomposan ampas tebu dilakukan di dalam kantong hitam (Polybag). Analisis kualitas kompos ditentukan berdasarkan parameter suhu, kadar air dan rasio $\mathrm{C} / \mathrm{N}$ yang diamati selama 18 hari. Pada penelitian ini, penggunaan Trichoderma (LBKURCC1 dan LBKURCC2) dan Pseudomonas (LBKURCC54 dan LBKURCC59) sebagai bioaktivator pada campuran bahan kompos memberikan perbedaan yang
\end{abstract}


nyata terhadap kontrol pada nilai rasio $\mathrm{C} / \mathrm{N}$ dengan nilai $\mathrm{P}>0,05$. Rasio $\mathrm{C} / \mathrm{N}$ tertinggi adalah dari P5 $(28,43)$ dan terendah adalah dari P2 $(5,17)$.

Kata kunci : ampas tebu, bioaktivator, Pseudomonas, trichokompos, Trichoderma

\section{PENDAHULUAN}

Tebu (Saccharum officinarum) merupakan tanaman yang mengandung kadar gula tinggi dan banyak digunakan sebagai bahan baku pembuatan gula pasir atau dapat dinikmati secara langsung dengan menggiling batang tebu kemudian diambil sarinya. Ampas tebu dari pengambilan sari tidak dimanfaatkan dengan baik dan sering dibuang sebagai limbah. Ampas tebu yang masih mengandung air, gula, serat dan mikroba, apabila ditumpuk akan menimbulkan masalah lingkungan, pandangan dan bau yang tidak sedap (Rahimah et al., 2015). Pengomposan merupakan salah satu strategi yang dapat dijadikan alternatif untuk mengatasi limbah ampas tebu ini. Secara kimiawi ampas tebu mengandung selulosa, hemiselulosa dan lignin yang berpotensi sebagai sumber karbon dalam pembuatan kompos.

Proses pengomposan dapat dipercepat dengan penambahan berbagai dekomposer yang mengandung mikroorganisme. Mikroorganisme yang biasanya digunakan sebagai decomposer adalah mikroorganisme pendegradasi selulosa yang baik (Ribeiro et al., 2017). Mikroorganisme dapat diperoleh dari berbagai sumber seperti kotoran ternak (manure), atau mikroba inokulan (microbeinoculant) (Murbandono, 2006). Trichokompos merupakan salah satu bentuk pupuk organik yang mengandung cendawan antagonis Trichoderma sp.. Jamur Trichoderma sp. yang terkandung dalam kompos berfungsi sebagai biodekomposer untuk mempercepat proses dekomposisi pada kompos dengan tujuan menghasilkan kompos yang bermutu (Juliana et al., 2017). Menurut Ginanjar et al. (2016), Trichoderma sp dalam kompos dapat dijadikan agen biokontrol dalam mengendalikan Organisme Pengganggu Tanaman (OPT) penyakit tular tanah.

Bakteri Pseudomonas stutzeri (LBKURCC54 dan 59) merupakan bakteri hasil isolasi dari umbi tanaman dahlia (Robi'a et al., 2012). Bakteri Pseudomonas stutzeri memiliki aktvitas enzim selulotik secara berturut- turut sebesar 1,85 x $10^{-2}$ U/mg dan 3,6 x 10 ${ }^{-2} \mathrm{U} / \mathrm{mg}$ (Marlinda et al., 2014). Pada penelitian ini akan digunakan Trichoderma (LBKURCC1 dan LBKURCC2) dan Pseudomonas (LBKURCC54 dan LBKURCC59) sebagai bioaktivator. Keempat mikroba tersebut digabung dalam media starter dengan beberapa variasi. Tujuannya untuk melihat kemampuan dari gabungan keempat mikroba tersebut dalam proses pengomposan. Trichoderma sp. LBKURCC1 mampu membentuk koloni baru, biasanya disebut kolonisasi. Kolonisasi ini menuju ke arah ketiga isolat patogen 
pada saat diinkubasi untuk uji, namun kemampuannya berbeda-beda (Saryono et al., 2018). Berdasarkan hasil pengamatan, Penicillium sp. LBKURCC75 dan Penicillium sp. LBKURCC77 juga melakukan kolonisasi menuju arah Trichoderma sp. LBKURCC1. Hal ini terjadi karena Trichoderma sp. LBKURCC1 tidak memiliki kemampuan antagonisme yang besar terhadap kedua isolat tersebut. Penicillium diketahui memiliki kemampuan mengeluarkan senyawa antifungal, seperti festuclavine yang dapat menghambat sintesis DNA dan RNA (Kumar et al., 2018).

Penelitian ini dilakukan bertujuan untuk mempelajari kemampuan isolat jamur Trichoderma sp (LBKURCC1, LBKURCC2) dan bakteri selulolitik Pseudomonas stutzeri (LBKURCC54 dan LBKURCC59) sebagai bioaktivator trichokompos. Analisis kualitas trichokompos seperti suhu, kadar air, dan rasio $\mathrm{C} / \mathrm{N}$ selama proses pengomposan berlangsung bertujuan untuk melihat pengaruh bioaktivator terhadap pengomposan.

\section{BAHAN DAN METODE}

\section{Peremajaan bioaktivator.}

Jamur dan bakteri yang digunakan merupakan kultur koleksi dari Laboratorium Biokimia FMIPA-Universitas Riau, lalu diremajakan di dalam media agar miring. Jamur dinkubasi selama 4 hari di suhu kamar, sedangkan bakteri diremajakan selama 24 jam di suhu $37^{\circ} \mathrm{C}$.

Jamur dan bakteri tersebut diinokulasi ke media cair untuk pembuatan inokulum. Satu ose jamur dan bakteri diinokulasi ke media cair yang telah disterilkan, lalu diinkubasi pada suhu yang sesuai selama 3 hari. Untuk jamur yang sudah bisa langsung digunakan, namun untuk bakteri dapat diukur jumlah sel dalam $1 \mathrm{ml}$ dengan absorbansi $660 \mathrm{~nm}$, dimana untuk $1 \mathrm{ml}$ kekeruhannya setara dengan OD 0,1. Setiap inokulum diambil $17 \mathrm{~mL}$, lalu dicampurkan ke media starter hingga homogen. Setiap inokulum yang dicampurkan total akhirnya adalah $50 \mathrm{~mL}$.

\section{Persiapan media starter.}

Bahan media starter terdiri dari $300 \mathrm{~g}$ dedak, $25 \mathrm{~g}$ gula merah, dan $25 \mathrm{~g}$ terasi. Semua bahan dihomogenkan dengan cara pemanasan. Setelah dingin dapat digunakan ke tahap selanjutnya. Media starter tersebut ditambahkan dengan isolat jamur LBKURCC1 (J1), jamur LBKURCC2 (J2), bakteri LBKURCC54 (B1), dan bakteri LBKURCC59 (B2) dengan kombinasi isolat starter sebagai berikut:

Starter 1 : gabungan Jamur LBKURCC1, jamur LBKURCC2 dan bakteri LBKURCC54 (J1 + J2 + B1) 
Starter 2 : gabungan Jamur LBKURCC1, jamur LBKURCC2 dan bakteri LBKURCC59 (J1 + J2 + B2)

Starter 3 : gabungan Jamur LBKURCC1, bakteri LBKURCC54 dan bakteri $\operatorname{LBKURCC59}(\mathrm{J} 1+\mathrm{B} 1+\mathrm{B} 2)$

Starter 4 : gabungan Jamur LBKURCC2, bakteri LBKURCC54 dan bakteri LBKURCC59 (J2 + B1 + B2)

Starter 5 : gabungan Jamur LBKURCC1, jamur LBKURCC2, bakteri LBKURCC54 dan bakteri LBKURCC59 (J1+ J2 + B1 + B2)

\section{Persiapan media kompos}

Ampas tebu ditimbang $6 \mathrm{~kg}$ dan $3 \mathrm{~kg}$ kotoran ayam, diaduk homogen. Media starter yang sudah dicampur homogen dengan kultur bioaktivator ditambahkan air hingga 8,1 L. Setelah itu media starter tersebut dituang merata ke campuran kompos hingga kadar kelembabannya mencapai 30-40\%.

\section{Proses pengomposan.}

Setiap tumpukan diisi Ampas tebu (AT) dan kotoran ayam dengan perbandingan 2:1 dan ditambah air untuk kontrol dan campuran media starter untuk perlakuan. Perlakuan untuk pengomposan adalah sebagai berikut:

$\mathrm{P} 0 \rightarrow$ Kontrol (ampas tebu + kotoran ayam + air)

$\mathrm{P} 1 \rightarrow$ Perlakuan 1 (ampas tebu + kotoran ayam + starter 1$)$

$\mathrm{P} 2 \rightarrow$ Perlakuan 2 (ampas tebu + kotoran ayam + starter 2 )

P3 $\rightarrow$ Perlakuan 3 (ampas tebu + kotoran ayam + starter 3 )

$\mathrm{P} 4 \rightarrow$ Perlakuan 4 (ampas tebu + kotoran ayam + starter 4 )

P5 $\rightarrow$ Perlakuan 5 (ampas tebu + kotoran ayam + starter 5)

Pengomposan dilakukan selama 18 hari. Masing-masing sampel dibuat tiga kali pengulangan, sehingga jumlah sampel menjadi 18 sampel (6 sampel x 3 kali ulangan). Kedelapan belas sampel kompos tersebut dibuat di dalam kantong plastik tanaman (polybag), lalu Semua bahan diaduk homogen dan dimasukkan ke dalam polybag dan ditutup dengan terpal dengan tujuan pengomposan dilakukan secara anaerob.

\section{Penanganan sampel kompos}

Kompos diaduk dengan menggunakan garpu besi setiap tiga hari sekali (pada hari 0, 3, 6, 9, 12, 15, dan 18). Pengomposan dilakukan selama 18 hari. Perubahan suhu selama proses pengomposan diukur setiap satu kali sehari, sedangkan kadar air diukur tiga hari sekali. Analisis kadar kandungan hara Coragnaik (Black dan walkey 1965), N-total (metode Kjeldahl secara titrasi), dan rasio $\mathrm{C} / \mathrm{N}$ dilakukan pada hari ke $0,6,12$, dan 18 . Data hasil penelitian berupa 
pengukuran suhu, kadar air, unsur hara $\mathrm{C}$-Organik dan $\mathrm{N}$-total dan rasio $\mathrm{C} / \mathrm{N}$ dianalisis menggunakan ANOVA dilanjutkan dengan uji Duncan jarak berganda untuk melihat perbedaan dari setiap variasi percobaan.

\section{HASIL DAN PEMBAHASAN}

Isolat LBKURCC1 merupakan spesies T.asperellum, bentuk sporanya seperti serbuk yang memadat yang jika diambil akan mudah berserakan. Ukuran koloninya tidak terlalu besar hingga inkubasi hari ketujuh. Pada hari ketiga tepi isolat berwarna putih dengan warna hijau di bagian tengah, dan hari ketujuh seluruh koloni berwarna hijau. Perkembangan koloni isolat ini sangat lambat dibandingkan isolat LBKURCC2. Isolat LBKURCC2 merupakan spesies T.viride, bentuk koloninya seperti karpet, seperti serabut. Hari ketiga ukuran koloni sudah memenuhi cawan petri. Pada waktu inkubasi hari ketiga tepi koloni berwarna hijau dan putih di bagian tengah. Pada inkubasi hari ketujuh seluruh koloni berwarna hijau. Perkembangan koloni isolat ini sangat cepat.

Pseudomonas (LBKURCC54 dan LBKURCC59) merupakan spesies yang sama, yaitu $P$. stutzeri. Warna koloni yaitu kuning dengan permukaan yang mengkilat. Hasil dari pengamata di bawah mikroskop diperoleh sel kedua bakteri tersebut adalah basil dengan warna merah muda, menunjukkan kedua isolat adalah bakteri grm negatif. Bentuk koloni dari isolat LBKURCC, LBKURCC2, LBKURCC54, dan LBKURCC59 dapat dilihat pada Gambar 1.

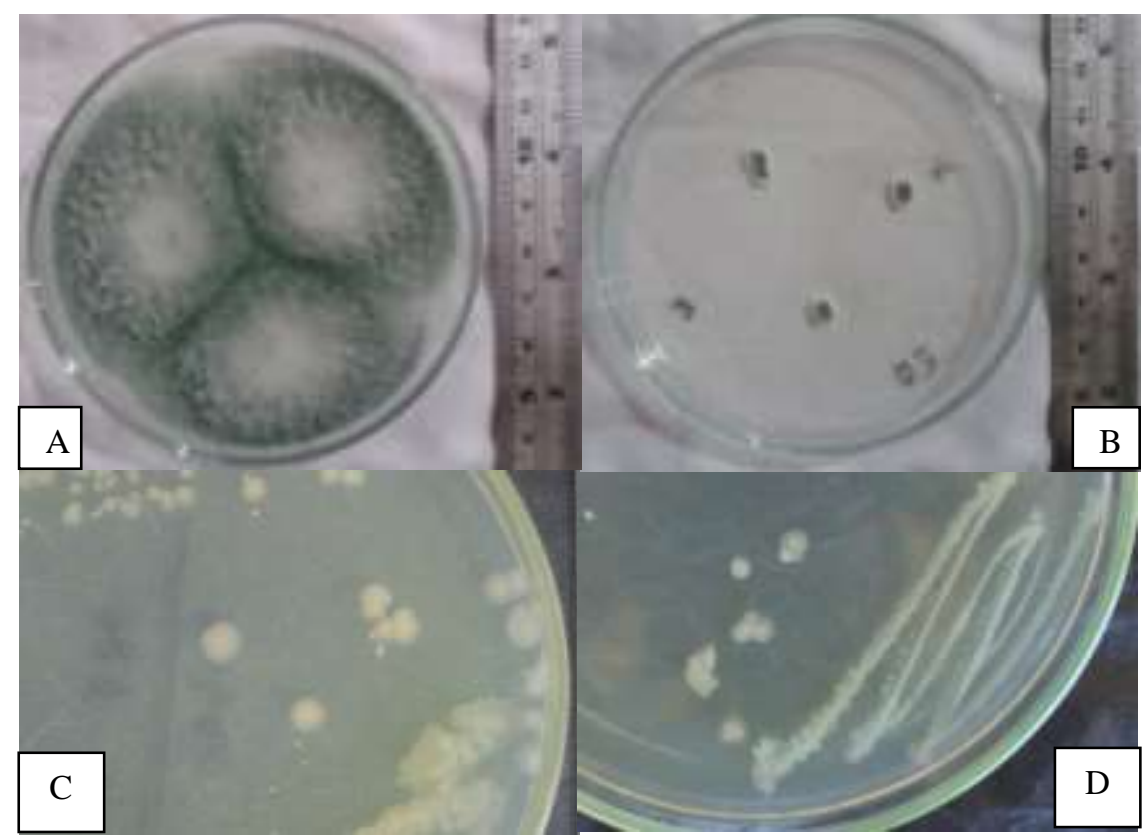

Gambar 1. (A) T. viride LBLURCC2, (B) T. asperellum LBKURCC1, (C) P. stutzeri LBKURCC54, (D) P. stutzeri LBKURCC59. 
Proses pengomposan menggunakan bioaktivator sangat memiliki pengaruh karena selain akan mendekomposisi bahan organik juga akan meningkatkan kadar $\mathrm{N}$ sebagai hara tambahan bagi kelangsungan hidup mikroba tersebut. Proses pembuatan kompos merupakan sistem kerjasama beberapa mikroba pemecah selulosa yang mempunyai ragam sifat fisiologis. Beberapa mikroba tersebut dapat dijumpai di alam, khususnya fungi jenis Trichoderma viride. Proses pengomposan ampas tebu pada penelitian ini menggunakan jamur dan bakteri inokulum yang akan melakukan proses fermentasi, yaitu Trichoderma (LBKURCC1 dan LBKURCC2) dan Pseudomonasszutzeri (LBKURCC54 dan LBKURCC59).

Gaur (1982) mengungkapkan, bahwa pada proses pengomposan akan terjadi penguraian bahan organik oleh aktivitas mikroba, yaitu mikroba akan mengambil air, oksigen, dan nutrisi dari bahan organik yang kemudian bahan organik tersebut akan mengalami penguraian dan membebaskan $\mathrm{CO}_{2}$ dan $\mathrm{O}_{2}$. Hal ini terjadi pada proses pengomposan dengan aktivator fungi dan tanpa aktivator fungi, tetapi pada pengomposan dengan aktivator fungi proses pematangan kompos dipercepat oleh mikroba tersebut.

Trichoderma sp. merupakan organisme pengurai, juga sebagai agen hayati dan stimulator pertumbuhan tanaman. Beberapa spesies Trichoderma telah dilaporkan sebagai agensia hayati seperti T. harzianum, $T$. viride, dan $T$. konigii yang berspektrum luas pada berbagai tanaman pertanian. Trichoderma bisa sebagai biodekomposer, mendekom-posisi limbah organik menjadi kompos yang bermutu, serta dapat berlaku sebagai biofungisida (Suhesy \& Adriani, 2014). Saryono et al. (2018) juga berhasil mengisolasi Trichoderma yang mampu mendegradasi selulosa. Di sisi lain, Ribeiro et al. (2017) menyatakan bahwa Pseudomonas sp. merupakan bakteri yang memiliki sifat pendegradasi selulosa yang baik.

\section{Analisis suhu}

Pengukuran suhu dilakukan setiap hari selama 18 hari menggunakan termometer terhadap sampel trichokompos secara langsung. Pengukuran dilakukan dengan cara memasukkan termometer hingga ke bagian tengah sampel. Jika kelembaban pada kompos tinggi, maka akan berpengaruh pada suhu kompos. Suhu dari setiap variasi trichokompos ampas tebu yang dilakukan nilainya tidak jauh berbeda, berkisar antara $29-44^{\circ} \mathrm{C}$, dapat dilihat pada Gambar 2. 
Peningkatan suhu merupakan salah satu indikator keberhasilan suatu proses pengomposan. Suhu yang semakin tinggi dari awal pengomposan hingga hari ke 13 menunjukkan sudah terjadinya aktivitas mikroba di dalam media kompos, seperti degradasi komposisi media ataupun melakukan reaksi redoks terhadap unsur hara di dalamnya. Suhu yang semakin tinggi juga menunjukkan kadar oksigen di dalam media kompos dalam keadaan tinggi. Jika kadar oksigen tinggi, maka proses dekomposisi akan semakin cepat terjadi dan mencapai tahap kematangan kompos. Menurut Isroi (2008) suhu media kompos yang mencapai $60^{\circ} \mathrm{C}$ menunjukkan aktivitas pengomposan yang cepat sampai proses matang.

\section{Analisis kadar air}

Analisis kadar air dilakukan untuk melihat kelembaban udara pada kompos. Semakin tinggi kadar air yang diperoleh menandakan kompos terlalu lembab atau mengandung air yang akan berpengaruh terhadap hasil kompos. Perhitungan persen kadar air dilakukan sekali tiga hari dalam 18 hari, yaitu pada hari ke 3, 6, $9,12,15$, dan 18. Hasil rata-rata perhitungan dari perlakuan ini dapat dilihat pada Gambar 3.

Pengukuran kadar air dilakukan bertujuan untuk melihat perubahan kelembaban media kompos selama proses pengomposan. Tinggi rendahnya suatu kadar air berpengaruh pada kelembaban suatu media kompos. Begitu pula sebaliknya, jika kelembaban suatu media kompos tinggi, maka kadar air dari kompos juga akan tinggi. Jadi hasil pengukuran kadar air sama dengan mengukur suatu kelembaban. Kadar air pada penelitian ini berkisar antara 59-81\%, dengan kadar terendah bernilai 59,82\% pada P3 di hari ke 0 dan kadar tertinggi bernilai 81,12\% pada P4 di hari ke 12. Menurut Rynk (1992), Kandungan air 40 - 60\% adalah kisaran optimum untuk metabolisme mikroba. Apabila kelembaban di bawah $40 \%$, aktivitas mikroba akan mengalami penurunan dan aktivitasnya juga lebih rendah lagi pada kelembaban 15\%. Apabila kelembaban lebih besar dari $60 \%$ unsur hara akan tercuci dan terbuang, volume oksigen di dalam media kompos berkurang, akibatnya aktivitas mikroba akan menurun dan akan terjadi fermentasi anaerobik yang menimbulkan bau tidak sedap. 
Optimalisasi Trichokompos dari Ampas Tebu dengan Jamur Trichoderma sp. 39

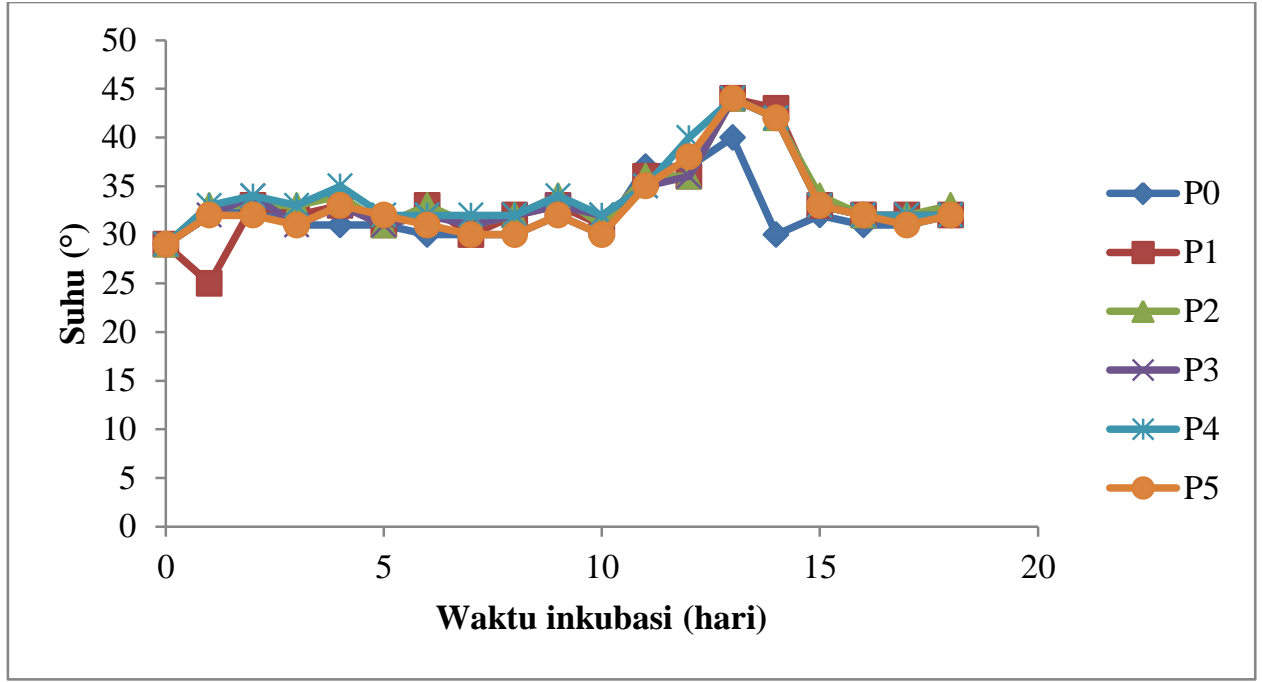

Gambar 2. Grafik hubungan waktu inkubasi dengan rata-rata persen suhu triichokompos ampas tebu.

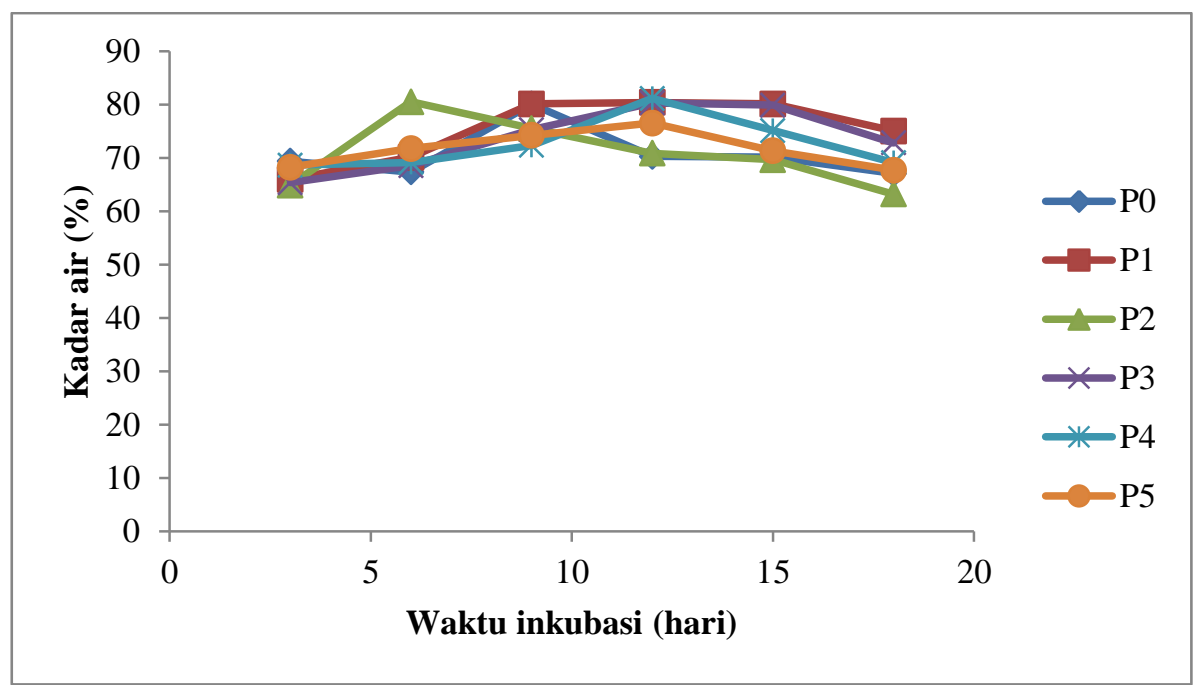

Gambar 3. Grafik hubungan waktu inkubasi dengan rata-rata persen kadar air trichokompos ampas tebu. 


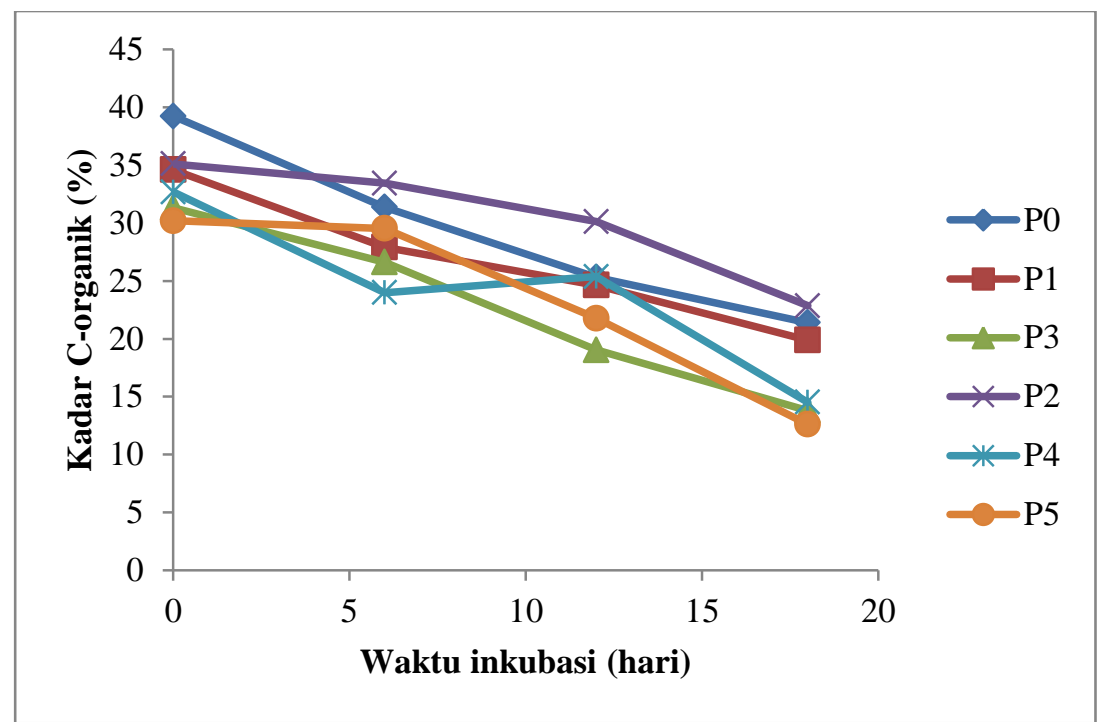

Gambar 4. Grafik hubungan waktu inkubasi dengan rata-rata persen kadar C-organik trichokompos ampas tebu.

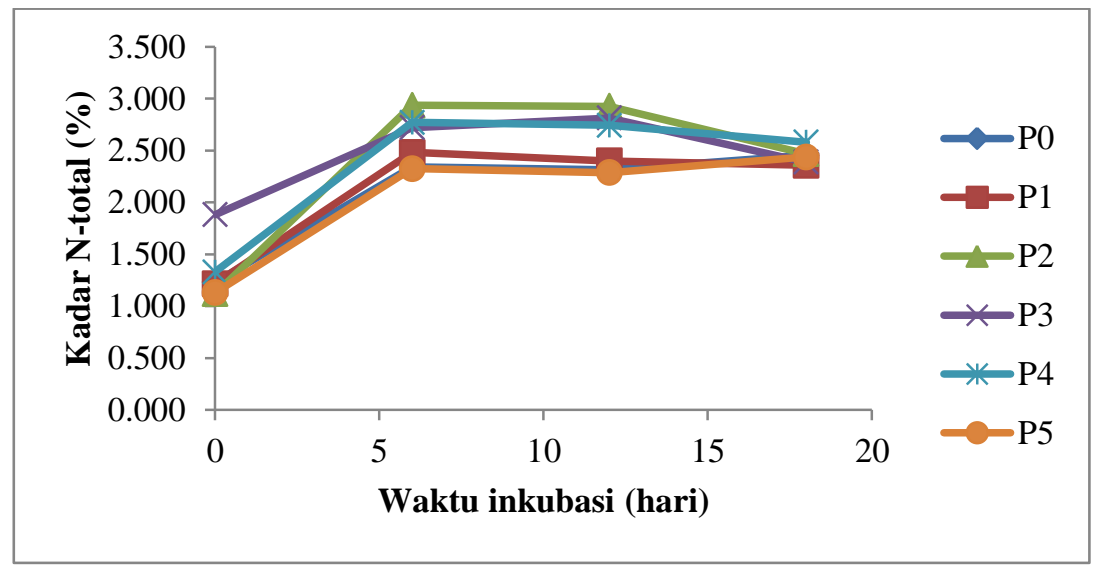

Gambar 5. Grafik hubungan waktu inkubasi dengan rata-rata persen kadar N-total trichokompos ampas tebu.

\section{Analisis rasio $\mathbf{C} / \mathbf{N}$ total}

Analisis $\mathrm{C}$-organik, $\mathrm{N}$-total, dan rasio $\mathrm{C} / \mathrm{N}$ total dilakukan pada inkubasi hari ke 0,6 , 12, dan 18 hari dengan metode yang berbeda. Hasil rata-rata pengukuran persen kadar C-organik tersedia dapat dilihat pada Gambar 4 dan hasil rata-rata pengukuran kadar N-total tersedia dapat dilihat pada Gambar 5.

C-organik pada penelitian ini diperoleh dengan nilai tertinggi dari variasi kompos P0 dengan nilai 39,22\% pada hari ke 0, sedangkan nilai terendah diperoleh dari variasi kompos P5 dengan nilai $12,61 \%$ pada hari ke 18 . Hasil Duncan berjarak ganda menunjukkan bahwa kadar C-organik pada hari fermentasi ke 0 berbeda signifikan $(\mathrm{P}>0,05)$ dengan waktu inkubasi lainnya dan perlakuan lainnya. Pada grafik 4.4 dapat dilihat bahwa kadar C-organik dari setiap perlakuan menurun dari hari ke 0 hingga hari ke 18 . 
Karbon merupakan unsur utama pada langkah awal terjadinya proses glikolisis yang nantinya akan menghasilkan energi. Energi tersebut akan berguna untuk mikroba dalam melakukan aktivitas lainnya. Selama proses pengomposan, $\mathrm{CO}_{2}$ akan menguap sehingga kadar karbon akan berkurang juga. Dalam pengomposan aerobik kurang lebih dua pertiga unsur karbon (C) menguap menjadi $\mathrm{CO}_{2}$ dan sisanya satu pertiga bagian bereaksi dengan nitrogen dalam sel hidup (Hastuti et al., 2017).

Berdasarkan Gambar 4 dan 5, kadar N-total terendah diperoleh dari P2 pada hari ke 0 dengan nilai 1,119\%. Sementara itu kadar N-total tertinggi diperoleh dari variasi kompos P4 pada hari k 18 dengan 2,581\%. Hasil uji Duncan berjarak ganda dari kadar N-total P2 pada hari fermentasi ke 18 berbeda signifikan $(\mathrm{P}>0,05)$ dengan waktu inkubasi lainnya dan perlakuan fermentasi P0 dan P5. Pada grafik 4.9 dapat dilihat perlakuan P1 memiliki garis grafik yang hampir lurus pada waktu inkubasi 6, 12, dan 18 dengan nilai masing-masing 2.481; 2.399; dan 2.357. Akan tetapi berdasarkan uji Duncan berjarak ganda ketiga nilai tersebut memiliki perbedaan yang signifikan.

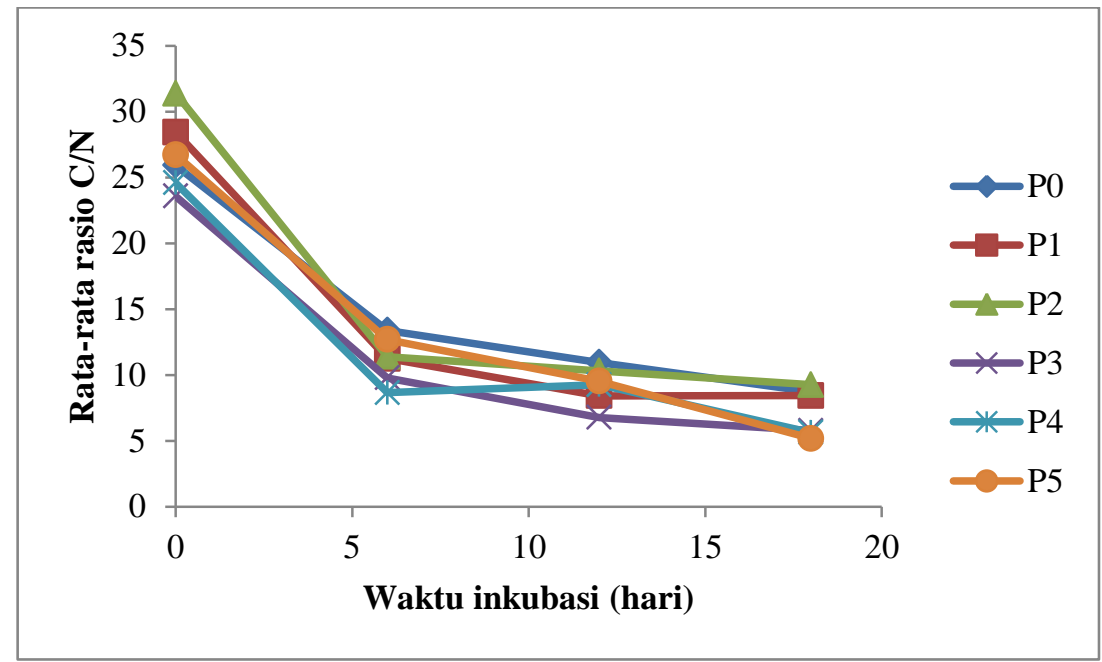

Gambar 6. Grafik hubungan waktu inkubasi dengan rata-rata rasio kadar C/N-total trichokompos ampas tebu.

\section{SIMPULAN}

Berdasarkan hasil penelitian ini, trichokompos ampas tebu dengan bioaktivator Trichoderma (LBKURCC1 dan LBKURCC2) dan Pseudomonas szutzeri (LBKURCC54 dan LBKURCC59) memberikan pengaruh yang nyata terhadap hasil trichokompos yang dihasilkan. 


\section{DAFTAR PUSTAKA}

Ginanjar, A., Husna Yetti., Sri Yoseva., 2016. Pemberian Pupuk trichokompos Jerami Jagung terhadap Pertumbuhan dan Produksi Bawang Merah (Allium ascalonicum L). JOM Faperta.3(1):1-11

Gaur, A.C., 1982. A manual of rural composting. in improving soil ferftility through organic recycling. Project Field Document No. 15. Food and Agricultural Organization of The United Nation, Rome.

Hastuti, S. M., Ganjar, S., Sri, S., 2017. Pengaruh kadar air terhadap hasil pengomposan sampah organik dengan metode composter tub. Jurnal Teknik Mesin. 6 (2): 2549 - 2888.

Isroi., 2008. Kompos. www.isroi.org. (diakses 16-04-2018).

Juliana., Umrah., Asrul., 2017. Pertumbuhan miselium Trichoderma sp. pada limbah cair tempe dan limbah air kelapa. Biocelebes. 12(2): 2580 - 5991.

Kumar, A., Monika, A., Ankur, G., Darshika, N., Surabhi, M., 2018. Secondary metabolism and antimicrobial metabolites of Penicillium. New and Future Developments in Microbial Biotechnology and Bioengineering. $47-68$

Marlinda, S., 2014. Uji Aktivitasdan Aktivitas Spesifik Ekstrak Kasar Enzim Selulolitik Dari Beberapa bakteri Endofit Umbi Tanaman Dahlia (Dahlia variabilis). Skripsi. FMIPA Universitas Riau.

Murbandono, L., 2006. Membuat Kompos. Penebar Swadaya, Jakarta.

Rahimah., Mardhiansyah., Yoza, D., 2015. The use of compost made from bagasse (Saccharum sp) with bioactivator Trichoderma spp. as a growing medium for seedlings Acacia crassicarpa. JOM FAPERTA. 2(1).

Ribeiro, N. Q., Thiago, P. S., Livia, M. A. S. C., Cibelli, P. C., Eustaquio, S. D., 2017. Microbial additives in the composting process. Ciencia $e$ Agrotecnologia. 41(2): 159 - 168.

Robi’a., Saryono., Pusfita, F., 2012. Skrining bakteri endofit dari umbi tanaman dahlia (Dahlia variabilis). Jurnal Ilmiah Sains Terapan. 3(5): 153-158.

Rynk, R., 1992. On-Farm Composting Handbook. Northeast Regional Agricultural Engineering Service Pub. No. 54. Cooperative Extension Service. Ithaca, N. Y. 199; 186pp. A classic in on-farm composting. Website: www.nraes.org. (diakses17-05-2018).

Saryono., Piska, F., Sari, N., Pratiwi, N. W., Ardhi, A., 2018. Morphological identification and hydrolytic enzymeproducing abilities of fungi associated with wilting banana plants (Musa sp.). Research Journal of Chemistry and Environment.

Suhesy, S., Adriani., 2014. Pengaruh probiotik dan Trichorderma terhadap hara pupuk kandang yang berasal dari feses sapi dan kambing. Jurnal Ilmiah Ilmu-ilmu Peternatakan. Vol 17 (2); 45 - 53. 